\title{
Effects of indomie noodle waste (INW) on serum lipid profile of broiler birds fed during the wet season
}

${ }^{1} *$ Yakubu, S. T., Olugbemi ${ }^{2}$, T. S., Onimisi ${ }^{2}$, P. and ${ }^{3}$ Lasisi, O. T.

${ }^{1}$ Department of Agricultural Technology, Nuhu Bamalli Polytechnic, Zaria.

${ }^{2}$ Department of Animal Science, Ahmadu Bello University, Zaria

${ }^{3}$ National Animal Production Research Institute (NAPRI), Shika, Zaria

Abstract*Corresponding author: 08060568218, simdahtanko@gmail.com

Instant noodles are widely consumed in Nigeria, with large of its by-products although high in energy but constituting environmental pollution in the production areas if allowed to lay waste. An eight-week feeding trial using 240 five-days old Hubbard flex broiler chicks was conducted to access the effect of feeding graded levels of indomie noodle waste (INW) in isonitrogenous diets on serum lipid profile of birds. Birds were allotted five treatments containing three replicates having sixteen birds per replicate in a completely randomized design. Five diets were compounded containing indomie noodle waste at 0, 25, 50, 75 and $100 \%$ replacing maize in the diets. Feed and water were provided ad libitum. At the end of the experiment, blood samples were collected from severed jugular veins of two birds per replicate and subjected to laboratory analysis for Total Cholesterol, High density lipoproteins, Low density lipoproteins and Triglycerides. Results showed that increase in $I N W$ in the diets of broilers increased total cholesterol $(148.24 \mathrm{mg} / \mathrm{dl}-192.06 \mathrm{mg} / \mathrm{dl}$, SD 61.68) and triglyceride $(27.07 \mathrm{mg} / \mathrm{dL}-91.52 \mathrm{mg} / \mathrm{dl}$, SD 40.79), favored high density lipoproteins $(37.38 \mathrm{mg} / \mathrm{dL}-77.34 \mathrm{mg} / \mathrm{Dl}$, SD 31.88), and lowered values for low density lipoproteins $(72.18 \mathrm{mg} / \mathrm{dL}-112.14 \mathrm{mg} / \mathrm{dL}, \mathrm{SD}$ 58.06) though there was no statistical difference $(P>0.05)$ across the treatments. Indomie noodle waste has the potential to replace maize up to $100 \%$ with good effects on High Density Lipoproteins, Total Cholesterol within range and lower Low Density Lipoproteins values.

Keywords: Chicks, lipid profile, indomie noodle waste

\section{Introduction}

Instant noodles are widely consumed throughout the world and it is a fast growing sector of the noodle industry (Owen, 2001). Instant noodle was introduced into Nigeria through import in 1988 under the 'indomie noodles' brand and local production of same brand started since 1995 and instant noodles are now eaten in most households across the country (Business news, 2006). Nigeria was the $13^{\text {th }}$ largest consumer of instant noodles as at 2007 according to the World Instant Noodle Association. Instant noodles are strips or strands cut from a sheet of dough made from wheat flour, starch, water, salt or kansui (an alkaline salt mixture of sodium carbonate, potassium carbonate, and sodium phosphate), and other ingredients (guar gum, tartrazine and spices) that improves the texture and flavor of noodles. Flour of hard wheat (Triticum aestivum L.) is the main primary ingredient ( $\mathrm{Fu}, 2008)$ and the addition of alkaline salts can help strengthen the structure and hence improve the firmness of the final product (Hou and Kruk, 1998). Indomie noodle waste contains crude protein 10.4 , ether extract 16.35 and crude fibre $0.9 \%$ as reported by Eniolorunda, (2008), which suggests it as a good source of energy.

Blood lipid profile has an important role in the performance and carcass quality of broilers. Due to the intense selection 
programs toward increasing body weight of broiler chickens, an excess of fatness in current modern stock is observed, this is becoming of substantial concern to poultry producers and consumers, as well. By the consumers, the acceptance of too oily carcass is no longer attractive (Tohala 2010). This study was carried out to check the effect of indomie noodle waste on serum lipid profile of broiler birds.

\section{Materials and methods Location}

The experiments were conducted at the Research and Learning Farm, Department of Animal Science, Ahmadu Bello University, Samaru-Zaria located within the northern Guinea savanna zone on latitude $11^{\circ} 9^{\prime} 45^{\prime} \mathrm{N}$ and longitude $7^{\circ} 38^{\prime}$ 8 'E, on an altitude of $610 \mathrm{~m}$ above sea level (Ovimaps, 2012).

\section{Source of indomie noodle waste}

The indomie noodle waste (INW) was sourced from Northern Noodles Limited, located at No 168, Refinery Industrial Layout, Kaduna-Kachia road, Kaduna state. The waste consisted majorly of underweight noodles.

\section{Experimental birds, design and management}

A total of 240 five days old chicks were used for this study. The chicks were randomly allocated to five dietary treatments with three replicates containing 16 birds per pen in a completely randomized design. Birds were raised in a deep litter poultry house with feed and water provided ad libitum. Heat and light were provided throughout the brooding period using kerosene stoves, electric bulbs and charcoal. Routine vaccines (Gumboro and Lasota) were administered.

\section{Experimental diets}

Five isonitrogenous diets were compounded with indomie noodle waste replacing maize at $0,25,50,75$ and $100 \%$. Birds were fed the starter $(23.9 \% \mathrm{CP})$ and finisher $(21 \% \mathrm{CP})$ diets for four weeks each and water was given ad libitum.

\section{Lipid profile analysis}

Blood samples were gotten from two birds per replicate after severing the jugular into sterile bottles. Samples were taken to the haematology laboratory of Faculty of Veterinary Science where the sera was separated and used for the determination of total cholesterol (TC), total triglyceride (TG), high density lipoprotein (HDL), low density lipoprotein (LDL).

\section{Data analysis}

Data were subjected to analysis of variance using the SAS 2001 package and means were separated using the Duncan's multiple range test.

\section{Results}

The result of serum lipid profile is presented in Table 3 with total cholesterol (TC) values fluctuating $(148.24 \mathrm{mg} / \mathrm{dl}-192.06 \mathrm{mg} / \mathrm{dl})$ across the treatments with no significant $(\mathrm{P}<0.05)$ difference though $0 \%$ INW had the lowest values for TC while birds on $25 \%$ INW diet had the highest values. High density lipoproteins (HDL) values showed no particular trend but significant $(\mathrm{P}<0.05)$ differences were recorded where $75 \%$ INW differed significantly $(\mathrm{P}<0.05)$ from 0 and $50 \%$ INW but was similar ( $\mathrm{P}>0.05)$ to birds on 25 and $100 \%$ INW diets. $50 \%$ INW was statistically $(\mathrm{P}<0.05)$ lower than 75 and 100\% INW. Low Density Lipoproteins (LDL) of birds fed $25 \%$ and $50 \%$ INW diets had the highest values while $100 \%$ INW had the lowest values though results were significantly $(\mathrm{P}>0.05)$ the same across the treatments. There was significant $(\mathrm{P}<0.05)$ difference in the result of Triglyceride with treatment 4 values higher $(\mathrm{P}<0.05)$ than other treatments. 
Yakubu, Olugbemi, Onimisi, and Lasisi

Table 1: Composition of broiler starter diet containing graded levels of Indomie Noodle Waste

\begin{tabular}{|c|c|c|c|c|c|}
\hline \multirow[b]{2}{*}{ Feed Ingredients (\%) } & \multicolumn{4}{|c|}{ Dietary levels of INW } & \multirow[b]{2}{*}{$100 \%$} \\
\hline & $\mathbf{0 \%}$ & $25 \%$ & $50 \%$ & $75 \%$ & \\
\hline Maize & 50.00 & 37.50 & 25.00 & 12.50 & 0.00 \\
\hline Indomie noodle waste & 0.00 & 12.50 & 25.00 & 37.50 & 50.00 \\
\hline Groundnut cake & 21.80 & 21.00 & 20.80 & 20.00 & 19.80 \\
\hline Soyabean cake & 20.00 & 20.00 & 20.00 & 20.00 & 20.00 \\
\hline Maize offal & 3.60 & 4.40 & 4.60 & 5.40 & 5.60 \\
\hline Limestone & 0.40 & 0.40 & 0.40 & 0.40 & 0.40 \\
\hline Bone meal & 3.00 & 3.00 & 3.00 & 3.00 & 3.00 \\
\hline Salt & 0.30 & 0.30 & 0.30 & 0.30 & 0.30 \\
\hline Lysine & 0.30 & 0.30 & 0.30 & 0.30 & 0.30 \\
\hline Methionine & 0.30 & 0.30 & 0.30 & 0.30 & 0.30 \\
\hline Premix* & 0.30 & 0.30 & 0.30 & 0.30 & 0.30 \\
\hline Total & 100 & 100 & 100 & 100 & 100 \\
\hline \multicolumn{6}{|l|}{ Calculated Analysis } \\
\hline $\mathrm{ME}(\mathrm{kcal} / \mathrm{kg})$ & 2820 & 2861 & 2901 & 2942 & 2982 \\
\hline Crude protein $(\%)$ & 23.92 & 23.84 & 23.95 & 23.87 & 23.98 \\
\hline Crude fibre $(\%)$ & 5.75 & 5.58 & 5.41 & 5.24 & 5.07 \\
\hline Ether extract $(\%)$ & 4.61 & 6.10 & 7.62 & 9.11 & 10.62 \\
\hline Calcium $(\%)$ & 1.02 & 1.03 & 1.03 & 1.04 & 1.05 \\
\hline Avail Phos (\%) & 0.55 & 0.54 & 0.53 & 0.53 & 0.53 \\
\hline Meth + Cys (\%) & 0.97 & 0.92 & 0.88 & 0.83 & 0.78 \\
\hline Lysine $(\%)$ & 1.34 & 1.30 & 1.27 & 1.23 & 1.20 \\
\hline Cost $/ \mathrm{kg}$ of diet & 95.80 & 95.32 & 95.20 & 94.68 & 94.56 \\
\hline
\end{tabular}

*Biomix premix supplied per kg of diet: vit. A,10000iu; vit D 3 2000iu; vit E 23mg; vit K 2mg; calcium pantothenate 2.5mg; vit B ${ }_{12}, 0.051 \mathrm{mg}$; Folic acid $0.75 \mathrm{mg}$; Chloride $300 \mathrm{mg}$; vit B $11.8 \mathrm{mg}$; vitB $_{2} 5 \mathrm{mg}$; manganese $40 \mathrm{mg}$; iron 20mg; zinc $30 \mathrm{mg}$; copper $3 \mathrm{mg}$; iodine $1 \mathrm{mg}$; cobalt $0.2 \mathrm{mg}$.

Table 2: Composition of broiler finisher diet containing graded levels of Indomie Noodle Waste

\begin{tabular}{|c|c|c|c|c|c|}
\hline \multirow[b]{2}{*}{ Feed Ingredients (\%) } & \multicolumn{4}{|c|}{ Dietary Levels of INW } & \multirow[b]{2}{*}{$100 \%$} \\
\hline & $\mathbf{0 \%}$ & $25 \%$ & $\mathbf{5 0 \%}$ & $75 \%$ & \\
\hline Maize & 58.00 & 43.50 & 29.00 & 14.50 & 0.00 \\
\hline Indomie noodle waste & 0.00 & 14.50 & 29.00 & 43.50 & 58.00 \\
\hline Groundnut cake & 21.80 & 21.15 & 20.52 & 19.90 & 19.27 \\
\hline Soyabean cake & 12.00 & 12.00 & 12.00 & 12.00 & 12.00 \\
\hline Maize offal & 3.45 & 4.10 & 4.73 & 5.35 & 5.98 \\
\hline Limestone & 0.50 & 0.50 & 0.50 & 0.50 & 0.50 \\
\hline Bone meal & 3.00 & 3.00 & 3.00 & 3.00 & 3.00 \\
\hline Salt & 0.30 & 0.30 & 0.30 & 0.30 & 0.30 \\
\hline Lysine & 0.35 & 0.35 & 0.35 & 0.35 & 0.35 \\
\hline Methionine & 0.35 & 0.35 & 0.35 & 0.35 & 0.35 \\
\hline Premix* & 0.25 & 0.25 & 0.25 & 0.25 & 0.25 \\
\hline Total & 100 & 100 & 100 & 100 & 100 \\
\hline \multicolumn{6}{|l|}{ Calculated Analysis } \\
\hline $\mathrm{ME}(\mathrm{kcal} / \mathrm{kg})$ & 2900 & 2947 & 2994 & 3041 & 3088 \\
\hline Crude protein $(\%)$ & 21.20 & 21.20 & 21.20 & 21.20 & 21.20 \\
\hline Crude fibre (\%) & 5.25 & 5.05 & 4.85 & 4.66 & 4.46 \\
\hline Ether extract $(\%)$ & 4.37 & 6.12 & 7.86 & 9.60 & 11.34 \\
\hline Calcium (\%) & 1.28 & 1.28 & 1.28 & 1.28 & 1.28 \\
\hline Avail Phos (\%) & 0.66 & 0.65 & 0.64 & 0.63 & 0.62 \\
\hline Meth + Cys (\%) & 0.94 & 0.88 & 0.83 & 0.77 & 0.72 \\
\hline Lysine (\%) & 1.17 & 1.13 & 1.09 & 1.05 & 1.01 \\
\hline - & 95.40 & 95.14 & 94.89 & 94.64 & 94.39 \\
\hline
\end{tabular}


Effects of indomie noodle waste on serum lipid profile of broiler chicken fed during the wet season

Table 3: Effect of diets containing graded levels of indomie noodle waste on the serum lipid Profile of birds

\begin{tabular}{|c|c|c|c|c|c|c|c|c|}
\hline \multirow[t]{2}{*}{ Parameters (mg/dL) } & \multicolumn{7}{|c|}{ Dietary levels of INW } & \\
\hline & $0 \%$ & $25 \%$ & $50 \%$ & $75 \%$ & $100 \%$ & SEM & LOS & \\
\hline $\mathbf{T C}$ & 148.24 & $4 \quad 192.06$ & 153.39 & & 190.77 & 172.73 & 27.54 & NS \\
\hline HDL & $42.54^{\mathrm{bc}}$ & $58.01^{\mathrm{abc}}$ & $37.38^{\mathrm{c}}$ & & $77.34^{\mathrm{a}}$ & $67.03^{\mathrm{ab}}$ & 14.23 & $*$ \\
\hline LDL & 92.81 & 112.14 & 112.14 & & 72.18 & 86.36 & 25.92 & NS \\
\hline TG & $27.07^{\mathrm{b}}$ & $48.98^{\mathrm{b}}$ & $36.09^{b}$ & & $91.52^{\mathrm{a}}$ & $42.54^{\mathrm{b}}$ & 18.21 & $*$ \\
\hline
\end{tabular}

\section{Discussion}

Total cholesterol values tend to increase as INW increased in the diet with the least mean value for the control which is similar to the findings of Alabi et al. (2012) that serum cholesterol may be slightly elevated by increased amount of INW. Alabi et al., (2012) reported increased values of serum cholesterol as INW increased in the diets, control diet had the least value $(154 \mathrm{mg} / \mathrm{dL})$ which varied significantly with $100 \%$ INW inclusion which recorded the highest value (338 mg/dL). Alabi and Ayoola (2010) recommended the inclusion of noodles at $50 \%$ to control the cholesterol level of the serum.

Higher value of HDL is desirable as birds on $75 \%$ INW diet $(77.34 \mathrm{mg} / \mathrm{dL})$ recorded the highest value. The non significant relationship that existed in the results of birds on 0,25 and $50 \%$ INW diets indicates a normal level of HDL, except for 50\% INW that fell below the normal/undesirable range $(<40 \mathrm{mg} / \mathrm{dL})$ which poses a risk of heart disease. The values obtained in 75 and $100 \%$ INW suggest that indomie noodle waste can replace maize up to $100 \%$ as it increases the level of HDL.

The mechanism of cholesterol reduction is thought to be through the lowering of plasma concentration of low density lipoproteins (Kane and Malloy, 1982), but the similar values for birds on 25 and $50 \%$ INW diets $(112.14 \mathrm{mg} / \mathrm{dL})$ indicates high concentration of LDL in the plasma that is near optimum (100-129mg/dL). Although values across the treatments are significantly the same, $75 \%$ INW recorded the lowest value followed by $100 \%$ INW which is a positive indication on $75 \%$ and $100 \%$ of INW inclusion in the diet as reflected on high density lipoproteins. Studies have shown that serum or plasma triglycerides of birds are strongly affected by heredity, nutrition, age, sex and environmental conditions (Sturkie 1986). In as much as differences occurred in this study, values were between 27.07 $91.52 \mathrm{mg} / \mathrm{dL}$ within the normal range of less than $150 \mathrm{mg} / \mathrm{dL}$ though $75 \%$ was on the high side as high levels of triglyceride indicates an elevation of low density lipoproteins.

\section{Conclusion}

The study showed that Indomie Noodle Wastes had the potential to replace maize up to $100 \%$ with good effects on High density lipoproteins, Total Cholesterol within range and lower Low density lipoproteins values.

\section{References}

Alabi, O. M. and Ayoola, M. O. 2010. Growth response of broiler finisher chickens fed with graded levels of indomie waste meal as replacement for maize. International Journal of Current Research and Review, 2(8):45-53.

Alabi, O. M., Aderemi, F. A., Ladokun, A. O., Lawal, T. E., Alabi, O. B. and Afolabi, K. D. 2012. Blood profile of broiler finisher birds fed diets 
with graded levels of indomie noodle waste meal in humid tropics. Elixir International Journal. Elixir Agriculture, 52:11269-11272

Businessnews 2006. "The noodles war. The NEWS-Nigeria's authoritative weekly news magazine". http://thenewsng.com/articles/857 $\Delta$ version=print. Retrieved 201205-19.

Eniolorunda, O. O., Taiwo, B. B. A., Oyewumi, O. O. and Adeyemi, $O$. A. 2008. Performance of laying hens fed graded levels of Indomie waste as a replacement for maize in ahumid $\quad \mathrm{t} \quad \mathrm{r}$ o environment. Research Journal of Animal Sciences, 2(5): 135-138.

Fu, B. X. 2008. Asian noodles: History, classification, rawmaterials and processing. Food Research International 41: 888-890.
Hou, G. and Kruk, M. 1998. Asian Noodle Technology. Technical Bulletin 20:10.

Kane, J. P. and Malloy, M. J. 1982. $\mathrm{T} r$ e a $\mathrm{t} \mathrm{m}$ e $\mathrm{nt}$ o f hypocholesterolemia. Medical clinics of North America, 66:537550.

Owen, G. 2001. Cereal processing technology. Cambridge: Wood head publishing

Sturkie, P. D. 1986. Lipid metabolism. In: Avian physiology. $4^{\text {th }}$ Edition. Springer Vilag, New York. Pp. 345-358

Statistical Analysis System. 2001. SAS Inc. User's Guide Version, 6.11.INC. Cary, North Carolina, USA.

Tohala, S. H. 2010. The relationship between blood lipid profile and performance of broilers fed two types of finisher diets. Iraqi Journal of Veterinary Sciences, Vol. 24(2) pp 87-91

Received: $25^{\text {th }}$ August, 2016 Accepted: 12 $2^{\text {th }}$ March, 2017 